\title{
CRYOPRESERVATION OF RABBITS SPERMATOZOA: EFFECT OF WARMING PROCEDURES, BREED AND POST- THAWING INCUBATION TIME
}

\author{
Samia Z. Meshreky ${ }^{1}$, I. El-Wardany ${ }^{2}$, A.A. Hemid ${ }^{2}$ and H.A. Abdollah $^{1}$ \\ 1- Animal Production Research Institute, Agricultural Research Centre, Giza, \\ Egypt, 2- Faculty of Agriculture, Ain-Shams University, Cairo, Egypt
}

\section{SUMMARY}

The present work was conducted to determine the effects of three warming procedures $\left(37^{\circ} \mathrm{C} / 15 \mathrm{~s}, 50^{\circ} \mathrm{C} / 12 \mathrm{~s}\right.$ or $\left.70^{\circ} \mathrm{C} / 10 \mathrm{~s}\right)$ and post-thawing incubation time $(0$ to $2 \mathrm{hrs}$ ) on in vitro assessment of sperm cryosurvival (motility) and acrosome status (intact, modified and completely detached) of New Zealand White (NZW) and Baladi Black (BB) rabbits. Semen was collected from mature bucks (6 in each breed) three times a week (two ejaculates per male/time). Only ejaculates with $>70 \%$ motility were considered, pooled and frozen in liquid nitrogen.

Post-thaw sperm motility and intact acrosome percentages were significantly $(P<0.001,0.01$ or 0.05) affected by different thawing procedures used, rabbit breeds, post-thaw incubation time and their interactions. There was a tendency to postthawing motility and intact acrosome improvements when using moderate $\left(50^{\circ} \mathrm{C} / 12 \mathrm{~s}\right)$ thawing procedure (27.44 and $39.44 \%)$ compared to rapid $\left(70^{\circ} \mathrm{C} / 10 \mathrm{~s}, 21.50\right.$ and $33.67 \%)$ and slower $\left(37^{\circ} \mathrm{C} / 15 \mathrm{~s}, 17.33\right.$ and $\left.28.33 \%\right)$ warming procedures. The highest percentage of post-thaw motility and intact acrosome (36.00 and $44.50 \%)$ were recorded when using moderate thawing procedure immediately after thawing, followed by 29.17 and 38.83\% with the same warming procedure after one hour incubation, then 28.50 and $36.83 \%$ with thaw rate at $70^{\circ} \mathrm{C} / 10$ s without incubation time. The higher percentage of structural abnormalities was observed with $B B$ rabbits when using slow or rapid thawing procedures compared to $N Z W$ rabbits. It can be concluded that moderate warming procedure $\left(50^{\circ} \mathrm{C} / 12 \mathrm{~s}\right)$ provided significantly more cryosurvival spermatozoa compared with the other thaw rates, especially in semen of the NZW rabbit bucks.

Keywords: Cryosurvival rabbit spermatozoa, warming procedures

\section{INTRODUCTION}

The cryopreservation of spermatozoa has allowed specific opportunities for the conservation of genetic resources through sperm banks, the guarantee of a constant commercial supply of semen, and collaboration in breed improvement programs (Holt, 1997). Most of domestic species (including the rabbit), semen cryopreservation is not yet under control (Salvetti et al., 2006). Successful preservation of spermatozoa irregardless of species is dependent on a series of steps aimed to reducing damage to the cell and securing adequate longevity in vitro and in vivo.

Many factors influencing semen quality through cryopreservation process are known include the technique of semen collection, the optimal dilution to obtain the

Issued by The Egyptian Society of Animal Production 
final concentration of spermatozoa (Okano et al., 2004), type of buffer and the addition of freezing cryoprotectant agents (Rijsselaere et al., 2002), the combination of extender and cooling rate during the freezing procedure (Pena and Linde-Forsberg, 2000), the thawing technique (Rota et al., 1998), as well as the use of a thawing medium and equilibration time (Linde-Forsberg et al., 1999) and possibly, also the removal of cryoprotectant after thawing.

Various studies carried out on freezing and thawing procedures for animal semen used different temperatures $\left(35-75^{\circ} \mathrm{C}\right)$ and times $(5-60 \mathrm{~s})$ for the thawing of straws (Velasco-Santamaria et al., 2006, Paulenz et al., 2007 and Muino et al., 2008). Most procedures used to thaw spermatozoa from rabbit have been modified from those considered to be standard for domestic ungulates and the optimal thawing procedure for rabbit spermatozoa frozen in straws remains to be established. Therefore, the aim of this study was to in vitro assess spermatozoal longevity (cryosurvival) of freezthawed rabbits spermatozoa as affected by warming procedures and rabbit breeds during different thawing-incubation time.

\section{MATERIALS AND METHODS}

Animals: Twelve mature New Zealand White (NZW) and Baladi Black (BB) rabbit bucks ( 6 in each breed) with an average body weight of $3.26 \pm 0.24$ and $2.97 \pm 0.18 \mathrm{~kg}$, respectively were used. They were housed in flat deck cages in rooms with controlled light $(16: 8 \mathrm{~h} \mathrm{~L}: \mathrm{N})$. Room temperature ranged from 25 to $28^{\circ} \mathrm{C}$. Animals received a commercial diet and water ad libitum.

Semen collection, processing and assessment of spermatozoa quality: Semen was collected three times a week (two ejaculates per male from each rabbits breed were collected, with a minimum of $30 \mathrm{~min}$ between ejaculate collections) with an artificial vagina. Only ejaculates exhibiting a white colour were used in the experiment, and if gel was present, it was removed. The volume was measured in a graduated conical tube. Sperm motility and morphological evaluations were performed in Tris diluent (0.25 M Tris, $88 \mathrm{mM}$ citric acid anhydrous, and $47 \mathrm{mM} \mathrm{D} \mathrm{(+)} \mathrm{glucose,} \mathrm{according} \mathrm{to}$ (Viudes de Castro et al., 1999). Only ejaculates with $>70 \%$ motility were considered. Sperm-cell concentration $\left(\times 10^{6} / \mathrm{ml}\right)$ of the original suspensions was determined using a hematocytometer. Motility and acrosomal status for cryopreserved sperm were made in the same way as for fresh sperm. The status of the acrosome of the normal sperm (intact, modified or completely detached) was evaluated as described by Tamuli and Watson (1994).

Freezing protocol: Following the initial assessment, the pooled fresh semen collected from each rabbit breeds were extended at $37^{\circ} \mathrm{C}$ with the dilution extender A (One part of fresh semen plus two parts of extender A). This dilution extender (Tris-Citric acidGlucose) has the following composition: $0.25 \mathrm{M}$ of Tris [hydroxymethyl] aminomethane, $88 \mathrm{mM}$ of anhydrous citric acid, and $47 \mathrm{mM}$ of $\mathrm{D}(+)$ glucose, and distilled water to $100 \mathrm{ml}$ (Moce et al., 2003). The tubes of diluted semen were placed in water bath of $37^{\circ} \mathrm{C}$ and gradually cooled to $5^{\circ} \mathrm{C}$ in refrigerator. Then, the semen was diluted at $5^{\circ} \mathrm{C}$ with freezing extender (B) which composed of extender $\mathrm{A}$ and cryoprotective agent (40 mM sucrose combined with $1.5 \mathrm{M}$ dimethylsulfoxide, DMSO). The diluted semen was mixed with the freezing extender as one part semen + two parts extender A + two parts extender B (1+4 or 1:5 ratio). The $\mathrm{pH}$ level was adjusted to 6.8 at final for the sperm survival. The extended semen was packed in 0.5 ml plastic straws, (IMV_ Technologies, L'Aigle, France), and sealed with polyvinyl- 
alcohol sealing powder and kept at $5^{\circ} \mathrm{C}$ for $90 \mathrm{~min}$ as equilibration period. The straws were placed horizontally in a rack approximately $5 \mathrm{~cm}$ above the liquid nitrogen surface for $10 \mathrm{~min}$, before plunging into liquid nitrogen container $\left(-196^{\circ} \mathrm{C}\right)$.

Warming procedures: The semen frozen straws in each rabbit breeds were divided into three groups and subjected to the one of the thaw procedures (slow: done at $37^{\circ} \mathrm{C}$ water bath for 15 second; moderate: done at $50^{\circ} \mathrm{C}$ water bath for $12 \mathrm{~s}$ and rapid: done at $70^{\circ} \mathrm{C}$ water bath for $10 \mathrm{~s}$ ) then removed from the bath and dried.

Assessment of frozen-thawed spermatozoa longevity: The frozen-thawed semen samples were incubated at $37^{\circ} \mathrm{C}$ for $2 \mathrm{~h}$ in the freezing medium. The percentages of post-thawing sperm motility and acrosomal status (intact, modified and completely detached) were assessed immediately (without incubation time, $0 \mathrm{hrs}$ ) and after one and two hours post-incubation.

Scanning electronic microscopy of rabbit spermatozoa: Sperm morphology was assessed by scanning electron microscopy. After rinsing with $0.1 \mathrm{M}$ Hepes buffer with $0.05 \mathrm{M} \mathrm{NaCl}(250-260 \mathrm{mOs})$, spermatozoa were fixed for $1 \mathrm{hr}$ in $1.5 \%$ glutaraldehyde and $1.5 \%$ paraformaldehyde in the same buffer. Then, they were washed by 3 changes of Hepes buffer and placed on small glass cover slips (12 x 12 $\mathrm{mm}$ ) coated with $0.1 \%$ poly-L-lysine solution. Post fixation was done with $1 \%$ osmium tetroxide in Hepes-NaCl buffer for $1 \mathrm{hr}$. Samples were then, dehydrated in a series of increasing concentrations of ethanol, critical point dried, sputter-coated with gold and examined with a Zeiss DSM-982 scanning electron microscope at an accelerating voltage of $30 \mathrm{kV}$.

Statistical analysis: The experimental trail was replicated seven times (each include 6 straws for each treatment). Data were analyzed using Least Squares Analysis of Variance using the GLM program of SAS (1998) according to the following fixed model:

$$
\mathrm{Y}_{\mathrm{ijklm}}=\mu+\mathrm{R}_{\mathrm{i}}+\mathrm{A}_{\mathrm{j}}+\mathrm{B}_{\mathrm{k}}+\mathrm{C}_{\mathrm{l}}+\mathrm{AB}_{\mathrm{jk}}+\mathrm{AC}_{\mathrm{il}}+\mathrm{BC}_{\mathrm{kl}}+\mathrm{ABC}_{\mathrm{jkl}}+\mathrm{e}_{\mathrm{ijklm}}
$$

Where $Y_{i j k l m}$ is the observation; $\mu$ is the overall mean; $R_{i}$ is the random effect of the replicate, $i=1,2, \ldots .7, A_{j}$ is the fixed effect of $j^{\text {th }}$ breed effect, $j=N Z W$ and $B B, B_{k}$ is the fixed effect of $\mathrm{k}^{\text {th }}$ warming procedures effect, $\mathrm{k}=$ slow, moderate and rapid, $C_{1}$ is the fixed effect of $1^{\text {th }}$ post-thaw incubation time effect, $1=0,1$ and $2 \mathrm{hrs}, \mathrm{AB}_{\mathrm{jk}}$, $\mathrm{AC}_{\mathrm{jl}}, \mathrm{BC}_{\mathrm{kl}}$ and $\mathrm{ABC}_{\mathrm{jkl}}=$ the fixed effect of interactions and $\mathrm{e}_{\mathrm{ijklm}}$ is the random error. The differences among means were tested using Duncan's New Multiple Range Test (Duncan, 1955).

\section{RESULTS AND DISCUSSION}

\section{Effect of warming procedures on post-thawing sperm quality:}

The percentage of post-thaw sperm motility and intact acrosome of rabbit spermatozoa were significantly $(\mathrm{P}<0.001)$ affected by different warming procedures used (Table 1). The results are in agreement with those reported by Bruce (2005) who found that the thawing procedure is of critical importance when using cryopreserved semen, which influence the post-thaw survival of a number of cells.

Warming semen with moderate warming procedure $\left(50^{\circ} \mathrm{C} / 12 \mathrm{~s}\right)$ had higher postthaw sperm motility and intact acrosome percentages $(27.44$ and $39.44 \%)$, followed by those thawing with rapid thawing (21.50 and 33.67\%), then slower thawing rate (17.33 and 28.33\%). Likewise, Eriksson and Rodriguez-Martinez (2000) found that increase thawing rate $\left(50\right.$ or $70^{\circ} \mathrm{C}$ compared to $\left.35^{\circ} \mathrm{C}\right)$ improved motility and NAR, which considered as an important parameter to monitor for evaluating the potential 
fertility of post-thaw semen. Also, Nur et al. (2003) found that thawing temperatures higher than $35^{\circ} \mathrm{C}$ improved post-thaw sperm motility, acrosomal integrity or sperm morphology. In addition, Moce et al. (2003) reported that thawing at $50^{\circ} \mathrm{C}$ gave better results (higher motility and NAR) than thawing at higher temperature $\left(70^{\circ} \mathrm{C}\right)$. However, Chen and Foote (1994) reported that the best rabbit sperm motility after thawing was obtained when the thawing temperature was $25^{\circ} \mathrm{C}$ for $1 \mathrm{~min}$. Generally, thawing stimulates metabolism and motion of sperm with intact plasma and acrosomal membranes (Bedford et al., 1999).

Table 1. Post-thawing motility and acrosome status of rabbit spermatozoa as affected by thawing procedures, rabbit breeds and post-thawing incubation time

\begin{tabular}{|c|c|c|c|c|}
\hline \multirow[b]{2}{*}{ Items } & \multirow{2}{*}{$\begin{array}{l}\text { Post-thawing } \\
\text { motility }(\%)\end{array}$} & \multicolumn{3}{|c|}{ Acrosome status (\%) } \\
\hline & & Intact & Modified & $\begin{array}{c}\text { Completely } \\
\text { detached }\end{array}$ \\
\hline \multicolumn{5}{|c|}{ Thawing procedures $\left({ }^{\circ} \mathrm{C} /\right.$ second $)$ : } \\
\hline $37^{\circ} \mathrm{C} / 15 \mathrm{~s}$ & $17.33^{c} \pm 0.54$ & $28.33^{c} \pm 0.37$ & $32.11 \pm 0.78$ & $39.56^{\mathrm{a}} \pm 0.66$ \\
\hline $50{ }^{\circ} \mathrm{C} / 12 \mathrm{~s}$ & $27.44^{\mathrm{a}} \pm 0.54$ & $39.44^{\mathrm{a}} \pm 0.37$ & $29.78 \pm 0.78$ & $31.33^{\mathbf{c}} \pm 0.66$ \\
\hline $70{ }^{\circ} \mathrm{C} / 10 \mathrm{~s}$ & $21.50^{\mathbf{b}} \pm 0.54$ & $33.67^{\mathbf{b}} \pm 0.37$ & $29.89 \pm 0.78$ & $36.44^{\mathbf{b}} \pm 0.66$ \\
\hline Significance & $* * *$ & $* * *$ & NS & $* * *$ \\
\hline \multicolumn{5}{|c|}{ Rabbit breeds: } \\
\hline NZW & $25.11^{\mathrm{a}} \pm 0.44$ & $36.67^{\mathrm{a}} \pm 0.30$ & $34.11^{\mathrm{a}} \pm 0.64$ & $29.22^{\mathbf{b}} \pm 0.54$ \\
\hline $\mathrm{BB}$ & $19.07^{\mathbf{b}} \pm 0.44$ & $30.96^{\mathbf{b}} \pm 0.30$ & $27.07^{\mathbf{b}} \pm 0.64$ & $43.33^{\mathrm{a}} \pm 0.54$ \\
\hline Significance & $* * *$ & $* * *$ & $* * *$ & $* * *$ \\
\hline \multicolumn{5}{|c|}{ Post-thawing incubation time (hours): } \\
\hline 0 & $29.33^{\mathrm{a}} \pm 0.54$ & $37.78^{\mathrm{a}} \pm 0.37$ & $25.94^{\mathbf{c}} \pm 0.78$ & $36.83 \pm 0.66$ \\
\hline 1 & $23.72^{\mathbf{b}} \pm 0.54$ & $33.56^{\mathbf{b}} \pm 0.37$ & $31.89^{\mathbf{b}} \pm 0.78$ & $34.56 \pm 0.66$ \\
\hline 2 & $13.22^{\mathbf{c}} \pm 0.54$ & $30.11^{c} \pm 0.37$ & $33.94^{\mathrm{a}} \pm 0.78$ & $35.94 \pm 0.66$ \\
\hline Significance & $* * *$ & $* * *$ & $* * *$ & NS \\
\hline
\end{tabular}

The improvement in cryosurvival spermatozoa values when using moderate warming procedure $\left(50^{\circ} \mathrm{C} / 12 \mathrm{~s}\right)$, could be attributed to a reduced recrystallization and cell damage. In pointed out that, Amann and Pickett (1987) reported that rapid thaw rate prevents recrystallization and its attendant damages. Also, results in Table (1) revealed that the slower and higher rates of thawing significantly $(\mathrm{P}<0.001)$ increased the percentages of completely detached acrosomes (39.56 and $36.44 \%$, respectively) compared to the moderate thawing rate $(31.33 \%)$.

Decreasing values of cryosurvival spermatozoa with $37^{\circ} \mathrm{C} / 15 \mathrm{~s}$ (Table 1) may be due to a slow thaw rate allows slower movement of water across membranes, and the metabolism of these sperm cells can be reestablished slowly, whereas a fast thaw rate may require cells to deplete nutrients rapidly in reestablishing metabolic functions and also may lead to frictional damage to the cell membranes because of rapid movement of water across the membranes to re-equilibrate the ion balance. Additionally, a slow thaw rate which allows time for small ice crystals, formed intracellularly during freezing, to recrystallize forming larger crystals that damage the cell structurally, leading to cell death (Mazur, 1984).

Decreasing cryosurvival spermatozoa percentages with increasing thawing temperature to $70^{\circ} \mathrm{C} / 10$ s (Table 1 ), may be due to rapid warming can induce osmotic 
stress on the spermatozoa because of the abrupt melting of the extra cellular solution, which can cause unbalanced rates of water influx and cryoprotectant egress, and can lead to swelling and lysis of cells (Mazur, 1984). In addition, Holt (2000) reported that increases in post-thawing temperature cause physical disruption of the plasma membrane due to subjecting it to structural rearrangements involving lipids and proteins. Moreover, Cabrita et al. (2001) concluded that high thaw temperatures can lead to denaturation of sperm enzymes in the peripheral area of the straws before the inside was thawed, as well as non-homogeneity in the thawing process and reduced viability. Additionally, an increase in the thawing temperature reduced recrystallization of intracellular ice, a process that can lead to the formation of larger and more stable ice crystals that could damage mitochondria (Fiser and Fairfull, 1990).

\section{Effect of rabbit breeds on post-thawing sperm quality:}

The percentage of post-thawing motility and acrosome status (intact, modified and completely detached) of spermatozoa were significantly $(\mathrm{P}<0.001)$ affected by rabbit breeds (Table 1). Irrespective to the thawing rates, semen collected from New Zealand White (NZW) rabbits yielded the higher sperm cryosurvival and intact acrosome compared with those received from Baladi Black (BB) rabbits. This finding is in accordance with Meshreky and Abbas (2001) who found that NZW had the best semen quality compared to Baladi Black rabbit breeds. The difference between breeds may be related to genetic factors. Similarly trends were obtained by Moce et al. (2003) observed significant differences between frozen-thawing spermatozoa of three rabbit lines in fertility rate (62 and $68 \%$ versus $45 \%$ for lines A, V and R, $\mathrm{P}<0.01)$. Nakagata et al. (1995) also found spermatozoa of Chinese mouse strain has a lower tolerance to cryopreservation than the Czechoslovakian mouse strain. In addition, Thurston et al. (2002) found that the variability of sperm of pigs from different individuals to survive freeze-thawing have indicated that there could be a genetic predisposition for freezability.

\section{Effect of post-thawing incubation time on sperm quality:}

Regardless of the warming procedures used and rabbit breeds, percentages of motility and intact acrosome were decreased $(\mathrm{P}<0.001)$ with the advancement of post-thawing incubation time at $37^{\circ} \mathrm{C}$ for up to 2 hours (Table 1). Similar observation was also reported by Abd El-Salaam (2002) and Meshreky et al. (2007). This phenomenon may be attributed to the decrease in the content of adenosine triphosphate, which could inactivated spermatozoa were apparently in capable of resynthesizing. This was accompanied by a precipitous fall in the rate of fructolysis (Salamon, 1970). However, Daader and Zeidan (2008) found that frozen-thaw semen incubated at $37^{\circ} \mathrm{C}$ showed a significant increase in post-thaw motility after one hour incubation and then a decrease after two hours at a significant level.

\section{Effect of interactions on post-thawing sperm quality:}

Post-thaw sperm motility, intact and modified acrosome percentages were significantly $(\mathrm{P}<0.05)$ affected by the interaction between warming procedures used and post-thaw incubation times, (Table 2). Frozen-semen thaw with moderate warming procedure had higher post-thaw sperm motility and intact acrosome percentages immediately after thawing (36.0 and 44.5\%), followed by the same warming procedure after one hour incubation (29.17 and $38.83 \%$ ), then rapid thaw 
rate immediately after thawing (28.5 and $36.83 \%$ ). The lowest values were recorded with slow warming procedure after $2 \mathrm{hr}$ of incubation $(9.17$ and $24.33 \%)$. Whereas, Ana et al. (2003) showed that no significant differences in the seminal parameters evaluated for the different thawing procedures used, except after $2 \mathrm{~h}$ of incubation at $42^{\circ} \mathrm{C}$, where significant differences were found.

Table 2. Post-thawing cryosurvival rabbit spermatozoa percentages as affected by interactions among warming procedures, post-thawing incubation time and rabbit breed

\begin{tabular}{|c|c|c|c|c|}
\hline \multirow{2}{*}{ Interactions } & \multirow{2}{*}{$\begin{array}{c}\text { Post-thawing } \\
\text { motility }(\%)\end{array}$} & \multicolumn{3}{|c|}{ Acrosome status (\%) } \\
\hline & & Intact & Modified & Completely detached \\
\hline \multicolumn{5}{|c|}{ Thawing procedures * incubation time: } \\
\hline $37^{\circ} \mathrm{C} / 15 \mathrm{~s} * 0 \mathrm{hr}$ & $23.50^{\mathbf{b c}} \pm 1.9$ & $32.00^{\text {cde }_{ \pm}} \pm 1.7$ & $26.50^{\mathbf{b c}} \pm 2.3$ & $41.50 \pm 3.2$ \\
\hline $1 \mathrm{hr}$ & $19.33^{\text {cd }_{ \pm 1.9}}$ & $28.67^{\mathrm{ef}} \pm 1.7$ & $33.17^{\mathbf{a b}} \pm 2.3$ & $38.17 \pm 3.2$ \\
\hline $2 \mathrm{hr}$ & $9.17^{\mathbf{f}_{ \pm}} \pm 1.9$ & $24.33^{\mathrm{f}} \pm 1.7$ & $36.67^{\mathrm{a}} \pm 2.3$ & $39.00 \pm 3.2$ \\
\hline $50^{\circ} \mathrm{C} / 12 \mathrm{~s} * 0 \mathrm{hr}$ & $36.00^{\mathbf{a}} \pm 1.9$ & $44.50^{\mathbf{a}} \pm 1.7$ & $28.00^{\mathbf{b c}} \pm 2.3$ & $29.17 \pm 3.2$ \\
\hline $1 \mathrm{hr}$ & $29.17^{\mathbf{b}} \pm 1.9$ & $38.83^{\mathbf{b}} \pm 1.7$ & $29.83^{\mathbf{a b c}_{ \pm}} \pm 2.3$ & $31.33 \pm 3.2$ \\
\hline $2 \mathrm{hr}$ & $17.17^{\mathrm{de}_{ \pm}} \pm 1.9$ & $35.00^{\text {bcd }} \pm 1.7$ & $31.50^{\mathbf{a b}} \pm 2.3$ & $33.50 \pm 3.2$ \\
\hline $70^{\circ} \mathrm{C} / 10 \mathrm{~s} * 0 \mathrm{hr}$ & $28.50^{\mathbf{b}} \pm 1.9$ & $36.83^{\mathbf{b c}} \pm 1.7$ & $23.33^{\mathbf{c}} \pm 2.3$ & $39.83 \pm 3.2$ \\
\hline $1 \mathrm{hr}$ & $22.66^{\mathrm{cd}_{ \pm}} \pm 1.9$ & $33.17^{\text {cde }_{ \pm}} \pm 1.7$ & $32.67^{\mathbf{a b}} \pm 2.3$ & $34.17 \pm 3.2$ \\
\hline $2 \mathrm{hr}$ & $13.33^{\mathrm{ef}_{ \pm}} \pm 1.9$ & $31.00^{\mathbf{d e}_{ \pm}} \pm 1.7$ & $33.67^{\mathbf{a b}} \pm 2.3$ & $35.33 \pm 3.2$ \\
\hline Significance & $*$ & * & * & NS \\
\hline \multicolumn{5}{|c|}{ Thawing procedures * rabbit breeds: } \\
\hline $37^{\circ} \mathrm{C} / 15 \mathrm{~s} * \mathrm{NZW}$ & $17.56^{\mathrm{c}} \pm 2.5$ & $28.22^{\mathbf{c}} \pm 1.3$ & $37.56^{\mathrm{a}} \pm 1.7$ & $34.22^{\mathbf{b}} \pm 1.1$ \\
\hline $\mathrm{BB}$ & $17.11^{\mathrm{c}} \pm 2.5$ & $28.44^{\mathbf{c}} \pm 1.3$ & $26.67^{\mathfrak{c}} \pm 1.7$ & $44.89^{\mathrm{a}} \pm 1.1$ \\
\hline $50^{\circ} \mathrm{C} / 12 \mathrm{~s} * \mathrm{NZW}$ & $31.44^{\mathrm{a}} \pm 2.5$ & $43.22^{\mathrm{a}} \pm 1.3$ & $31.00^{\mathbf{b c}} \pm 1.7$ & $25.78^{c} \pm 1.1$ \\
\hline $\mathrm{BB}$ & $23.44^{\mathbf{b c}_{ \pm}}+2.5$ & $35.67^{\mathbf{b}} \pm 1.3$ & $28.55^{\mathbf{c}} \pm 1.7$ & $36.89^{\mathbf{b}} \pm 1.1$ \\
\hline $70^{\circ} \mathrm{C} / 10 \mathrm{~s} * \mathrm{NZW}$ & $26.33^{\mathbf{a b}_{1}} \pm 2.5$ & $38.56^{\mathbf{b}} \pm 1.3$ & $33.78^{\mathbf{a b}} \pm 1.7$ & $27.67^{\mathbf{c}} \pm 1.1$ \\
\hline $\mathrm{BB}$ & $16.67^{\mathfrak{c}} \pm 2.5$ & $28.78^{\mathbf{c}} \pm 1.3$ & $26.00^{\mathbf{c}} \pm 1.7$ & $45.22^{\mathrm{a}} \pm 1.1$ \\
\hline Significance & $* * *$ & $* * *$ & $* *$ & $* *$ \\
\hline \multicolumn{5}{|c|}{ Rabbit breeds * post-thawing incubation time: } \\
\hline $\mathrm{NZW} * 0 \mathrm{hr}$ & $32.78^{a} \pm 1.8$ & $41.56^{\mathrm{a}} \pm 1.9$ & $27.56^{\mathbf{b c}} \pm 1.3$ & $30.89 \pm 1.7$ \\
\hline $1 \mathrm{hr}$ & $27.67^{\mathbf{a b}_{1}} \pm 1.8$ & $36.33^{\mathbf{a b}_{ \pm}} \pm 1.9$ & $36.22^{\mathrm{a}} \pm 1.3$ & $27.44 \pm 1.7$ \\
\hline $2 \mathrm{hr}$ & $14.89^{\text {cd }_{ \pm}} \pm 1.8$ & $32.11^{\mathbf{b c}_{ \pm 1.9}}$ & $38.56^{\mathbf{a}} \pm 1.3$ & $29.33 \pm 1.7$ \\
\hline $\mathrm{BB} * 0 \mathrm{hr}$ & $25.89^{\mathbf{b}} \pm 1.8$ & $34.00^{\mathbf{b}} \pm 1.9$ & $24.33^{\mathrm{c}} \pm 1.3$ & $42.78 \pm 1.7$ \\
\hline $1 \mathrm{hr}$ & $19.78^{\mathbf{c}} \pm 1.8$ & $30.78^{\mathbf{b c}_{ \pm}}+9$ & $27.56^{\mathbf{b c}_{ \pm}} \pm 1.3$ & $41.67 \pm 1.7$ \\
\hline $2 \mathrm{hr}$ & $11.56^{\mathrm{d}} \pm 1.8$ & $28.11^{\mathbf{c}} \pm 1.9$ & $29.33^{\mathbf{b}} \pm 1.3$ & $42.56 \pm 1.7$ \\
\hline Significance & $*$ & $* *$ & $*$ & NS \\
\hline
\end{tabular}

Post-thaw sperm survival and acrosome status percentages were affected $(\mathrm{P}<0.001$ or 0.01$)$ by interaction between different thawing procedures and rabbit breeds (Tables 2). The highest percentage of post-thaw sperm motility and intact acrosome percentage ( 31.44 and $43.22 \%$ ) were obtained with semen of NZW rabbits using moderate thawing procedure, followed by 26.33 and $38.56 \%$ with the same rabbit breed but with thaw rate at $70^{\circ} \mathrm{C} / 10 \mathrm{~s}$, then 23.44 and $35.67 \%$ with $\mathrm{BB}$ rabbits thaw with moderate warming procedure. Similarly, Moce et al. (2003) found significant differences between frozen-thawing spermatozoa of three rabbit lines (A, $\mathrm{V}$ and $\mathrm{R}$ ) and thawing rates $\left(50\right.$ or $70{ }^{\circ} \mathrm{C}$ for $10-12$ second), the best results for all lines were observed when sperm thawed at $50^{\circ} \mathrm{C}(85,84$ vs. $50 \%)$. Decreased or increased thawing rate increased $(\mathrm{P}<0.01)$ completely detached acrosome percentages 
from 36.89 to 44.89 and $45.22 \%$, respectively with moderate thawing rate in BB rabbits, whereas from 25.78 to 34.22 and $27.67 \%$ in NZW rabbits (Tables 2).

Post-thaw sperm motility, intact and modified acrosome percentages were affected $(\mathrm{P}<0.01$ or 0.05$)$ by interaction between rabbit breeds and post-thaw incubation time (Tables 2). Thawing spermatozoa of NZW or BB rabbits and incubated for $2 \mathrm{~h}$ at $37^{\circ} \mathrm{C}$, reduced sperm motility (longevity) and intact acrosome percentages, and increased modified acrosome. Semen collected from BB rabbit bucks ranked the second in cryosurvival of spermatozoa after NZW rabbit and gave its lowest values after thawing. Generally, the freeze-thaw process damages the anterior plasma membrane of sperm, which is the normal site of calcium exchange that alters ionic balance and increases intracellular calcium (Bedford et al., 1999). Therefore, the freezing and thawing process can stimulate both physiologic and nonphysiologic capacitation and acrosome reactions (Bradford and Buhr, 2002).

Interaction among different thawing procedures, post-thawing incubation time and rabbit breeds insignificantly affected any of the tested parameters.

\section{Structures of frozen-thawed spermatozoa}

The frozen-thawed spermatozoa of rabbit were analyzed for morphological changes under scanning electron microscope (S.E.M.) and showed either normal spermatozoa without any surface damage (intact acrosome) or ultra structure damage as ruptures of the plasma membrane in the acrosomal region during the cryopreservation stage, large areas of rough or disrupted acrosomal surface (the acrosome covered more than $50 \%$ of the head length. Results of S.E.M. confirmed that the semen cryopreservation induced a decrease of intact acrosomes, in addition, increased structure changes in bent midpiece and thickening of the midpiece, coiled tail, and detached tail (Plate $1 \& 2$ ). These observations are accordance with those obtained by Liu et al. (2004) who found damage in acrosome and sperm tail after freez-drying process in rabbits. In addition, this study documented the dimensions of rabbit sperm. The total length of rabbit spermatozoa was about 35-45 $\mu \mathrm{m}$ with an ovoid head of about $7-10 \mu \mathrm{m}$ in length and about $5 \mu \mathrm{m}$ in diameter.

Frozen-thawed semen with moderate warming procedure of NZW rabbits without incubation time showed the lowest damage in sperm acrosome and tail, followed by those thawing in the same warming procedure with the same rabbit breed after one hours of incubation time, then semen of the same rabbit breed with rapid warming procedure $\left(70^{\circ} \mathrm{C} / 10 \mathrm{~s}\right)$. After $2 \mathrm{hrs}$ post-thawing incubation, semen of $\mathrm{BB}$ rabbits thaw with slow or rapid warming procedures showed the highest percentage of abnormal sperm structure of acrosome and the connection between the sperm head and tail became so fragile that pipetting could easily cause head-tail separation (Plate $1 \&$ 2). These observation are agree with Mazur (1984) who found that mechanical damage or alteration of membrane molecules impedes proper sperm function, and both types of damage are affected by the rates of cooling, freezing, and warming. In the same relation, Polgar et al. (2004) observed that the freezing-thawing process increased the number of dead sperm cells from $18 \%$ to $46 \%$, at the same time, a significant $(\mathrm{P}<0.001)$ damage of acrosomal and tail membrane integrity. Nur et al. (2003) also found that thawing temperatures higher than $35^{\circ} \mathrm{C}$ improved post-thaw acrosomal integrity or sperm morphology. 


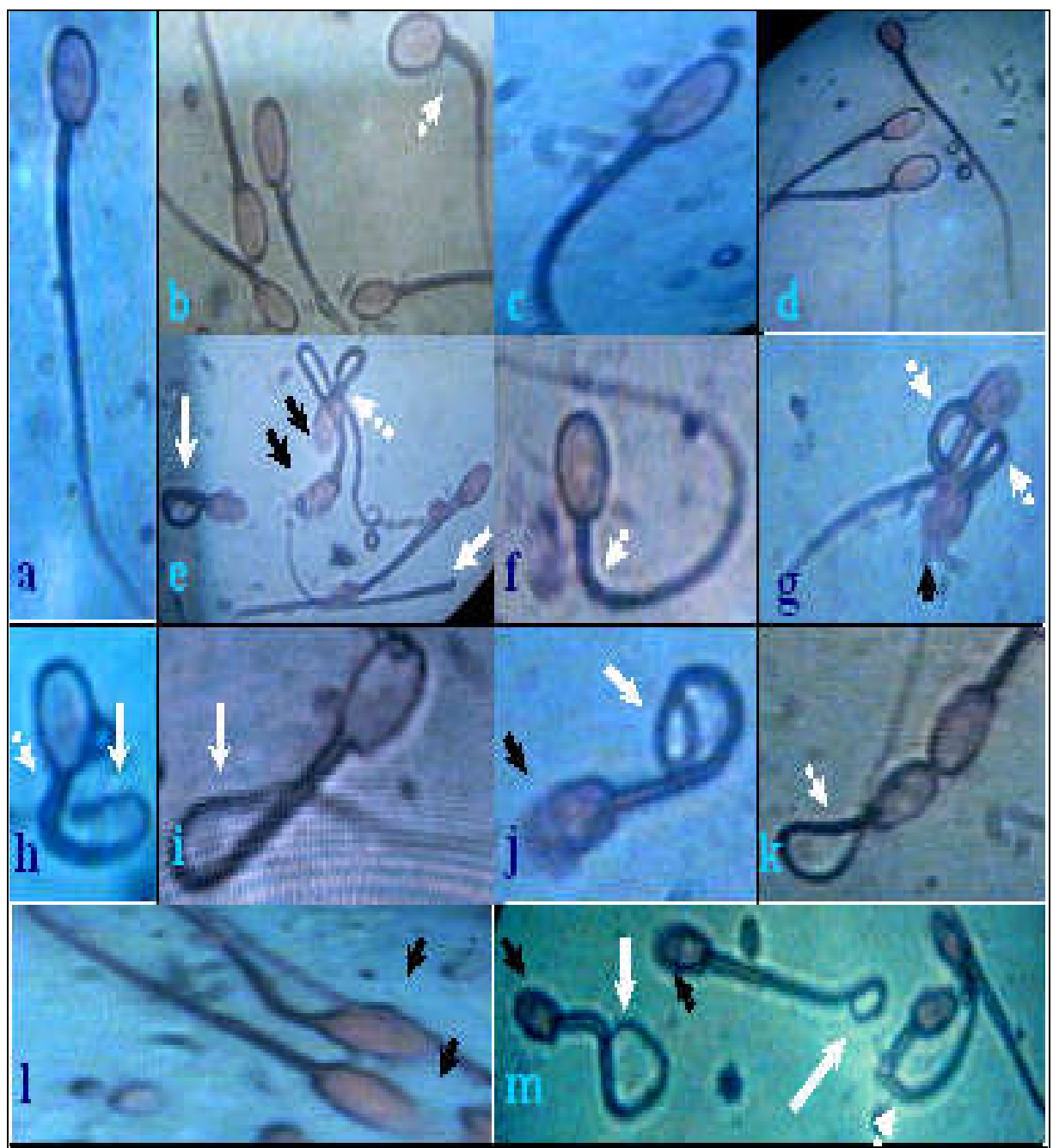

Plate 1. Phase-contrast of frozen-thawed rabbit spermatozoa: (a) normal viable sperm with intact acrosome. (b, c and d) viable sperm with gauzy and intact acrosome while non-viable sperm tended to be reddish. (e, $g$, $j$ and $l$ ) the membrane damage in the acrosome. (b, $f, g, I$ and $k$ ) bent midpiece. (e, $h, J, i$ and $m$ ) coiled tail. (e) detached tail. Black arrows indicate acrosome modified or completely detached and white arrows indicates abnormality in tail sperm, white arrow head indicates abnormality in neck and midpiece regions 


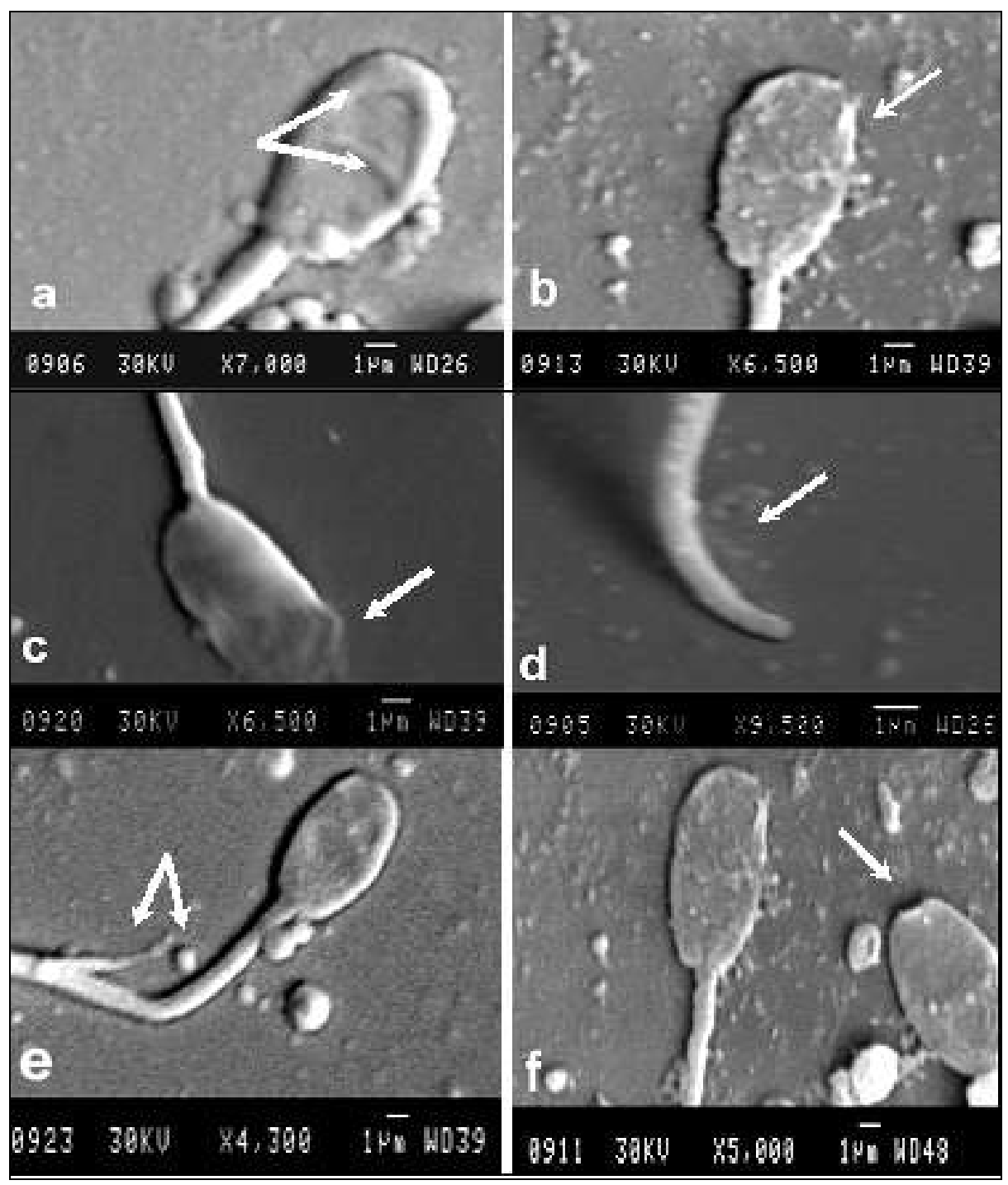

Plate 2. Scanning electron photograph of ultrastructure of frozen-thawed rabbit spermatozoa: (a) The sperm head shape is normal ovoid with intact acrosome. (b) Sperm with modified acrosome (head shows partly acrosomal damage). (c) Sperm with completely damaged acrosome (ruptured membrane). (d) Intact and bent tail (e) Sperm with coiled and ruptured tail. (f) Detached head (head-tail separation) 


\section{CONCLUSION}

It can be concluded that moderate warming procedure $\left(50^{\circ} \mathrm{C} / 12 \mathrm{~s}\right)$ provided significantly more cryosurvival spermatozoa compared with the other thawing procedures immediately after thawing, especially in semen of the NZW rabbit bucks.

\section{REFERENCES}

Abd El-Salaam, A.M., 2002. Studies on freezing of rabbit semen. M.Sc. Thesis, Faculty of Agriculture, Zagazig University, Zagazig, Egypt.

Amann, R.P. and B.W. Pickett, 1987. Principles of cryopreservation and a review of cryopreservation of stallion spermatozoa. J. Equine Vet. Sci., 7(3):145-173.

Ana, J.S., V. Astore, A. Sestelo, M. Rivolta, L.N. Jacome and J.J. Garde, 2003. Effect of thawing procedure on cryosurvival of deer spermatozoa: work in progress. Theriogenology, (60): 511-520.

Bedford, S.J., H.L. Gowdy and K. Hinrichs, 1999. Comparison of the longevity of motility of stallion spermatozoa incubated at $38^{\circ} \mathrm{C}$ in different capacitating media and containers. Theriogenology, 51:637-646.

Bradford, L.L. and M.M. Buhr, 2002. Function of cryopreserved horse semen is improved by optimized thawing rates. Journal of Equine Veterinary Science, 22(12): 546-550.

Bruce, E.E., 2005. Theoretical aspects of canine semen cryopreservation. Theriogenology, (64): 692-697.

Cabrita, E., L. Anel and M.P. Herrez, 2001. Effect of external cryoprotectants as membrane stabilizers on cryopreserved rainbow trout sperm. Theriogenology, (56): 623-635.

Chen, Y., R.H. Foote, 1994. Survival of rabbit spermatozoa frozen and thawed at different rates with and without seeding. Anim Reprod Sci, (35):131-43.

Daader, A.H. and A.S.B. Zeidan, 2008. Motility and acrosomal integrity of frozen rabbit Spermatozoa as affected by different Extenders, cryoprotectants and packaging methods. $9^{\text {th }}$ World Rabbit Congress - June 10-13, Verona - Italy, p: 339-342.

Duncan, D.B., 1955. Multiple range and multiple F-tests. Biometrics, (11): 1-42.

Eriksson, B.M. and H. Rodriguez-Martinez, 2000. Effect of freezing and thawing rates on the post-thaw viability of boar spermatozoa frozen in FlatPacks and Maxi-straws. Animal Reproduction Science, (63): 205-220.

Fiser, P.S. and R.W. Fairfull, 1990. Combined effect of glycerol concentration and cooling velocity on motility and acrosome integrity of boar spermatozoa frozen in $0.5 \mathrm{ml}$ straws. Mol. Reprod. Dev., (25): 123-129.

Holt, W.V., 1997. Alternative strategies for the long-term preservation of spermatozoa. Reprod. Fertil. Dev., 9: 309-319.

Holt, W.V., 2000. Fundamental aspects of sperm cryobiology: the importance of species and individual differences. Theriogenology, (53): 47-58.

Larry, J., A. Minter, J. Thomas and J. M. De Liberto, 2005. Influence of extender, freezing rate, and thawing rate on post-thaw motility, viability and morphology of coyote (Canis latrans) spermatozoa. Theriogenology, (64): 1898-1912.

Linde-Forsberg, C., B.S. Holst and G. Govette, 1999. Comparison of fertility data from vaginal vs. intrauterine insemination of frozen- thawed dog semen: a retrospective study. Theriogenology, (52):11-23. 
Liu, J.L., H. Kusakabe, Ch. Chang, H. Suzuki, D.W. Schmidt, M. Julian, R. Pfeffer, Ch.L. Bormann, X.C. Tian, R. Yanagimachi and X. Yan, 2004. Freeze-dried sperm fertilization led to term development in rabbits. Biology of Reproduction, (70): 1776-1781.

Mazur, P., 1984. Freezing of live cells: mechanisms and implications. Am. J. Physiol., 247: 125-142.

Meshreky, Samia Z. and H.E. Abbas, 2001. Effect of vitamin E and selenium injection on adaptive and reproductive performance of male rabbits under hot climatic conditions. Egyptian Society for Animal Reproduction and Fertility, $13^{\text {th }}$ Annual Congress (22-26 Jan.), 51-67.

Meshreky, Samia Z., I. El-Wardany, A.A. Hemid and H. Abd El-Sabour, 2007. Cryopreservation of rabbits spermatozoa: Effects of cryprotectant agents, clarified egg yolk and post-thawing incubation time. The $5^{\text {th }}$ Inter.Con.on Rabbit Prod. in Hot Clim., Hurghada, Egypt, 435 - 449.

Moce, E., J.S. Vicente and R. Lavara, 2003. Effect of freezing-thawing protocols on the performance of semen from three rabbit lines after artificial insemination, Theriogenology (60): 115-123.

Muino, R., M.M. Rivera, T. Rigau, J.E. Rodriguez-Gil and A.I. Pena, 2008. Effect of different thawing rates on post-thaw sperm viability, kinematic parameters and motile sperm subpopulations structure of bull semen. Animal Reproduction Science, (Article in press).

Nakagata, N., S. Ueda, K. Yamanouchi, M. Okamoto, Y. Matsuda, K. Tsuchiya, M. Nishimura, S. Oda, K. Koyasu, S. Azuma and Y. Toyoda, 1995. Cryopreservation of wild mouse spermatozoa Theriogenology, (43): 635-643.

Nur, Z., I. Dogan, M.K. Soylu and K. Ak, 2003. Effect of different thawing procedures on the quality of bull semen. Revue Med. Vet., (154): 487-490.

Okano, T., T. Murase, M. Asano and T. Tsubota, 2004. Effects of final dilution rate, sperm concentration and times for cooling and glycerol equilibration on postthaw characteristics of canine spermatozoa. J Vet Med Sci., (66):1359-64.

Paulenz, H., T. Adnøy and L. Soderquist, 2007. Comparison of fertility results after vaginal insemination using different thawing procedures and packages for frozen ram semen. Acta Vet. Scand., 49(1): 1-7.

Pena, A. and C. Linde-Forsberg, 2000. Effects of Equex, one- or two-step dilution, and two freezing and thawing rates on post-thaw survival of dog spermatozoa. Theriogenology, (54):859-875.

Polgar, Z.S., GY. Virag, B. Baranyai, S.Z. Bodo, A. Kovacs and E. Gocza, 2004. Evaluation of effects of cryopreservation on rabbit spermatozoa membranes with trypan blue-giemsa staining. Proc. $8^{\text {th }}$ World Rabbit Congress, Puebla, Mexico (pp.322-329).

Rijsselaere, T., A. Van Soom, D. Maes and A. de Kruif, 2002. Effect of centrifugation on in vitro survival of fresh diluted canine spermatozoa. Theriogenology, (57): 1669-1681.

Rota, A., C. Linde-Forsberg, J. Vannozzi, S. Romagnoli and H. Rodriguez-Martinez, 1998. Cryosurvival of dog spermatozoa at different glycerol concentrations and freezing/thawing rates. Reprod Dom Anim, (33):355-361.

Salamon, S., 1970. The survival of ram spermatozoa folloing pellet freezing below $79^{\circ} \mathrm{C}$. Australian Journal of Biological Science, (23):459-468. 
Salvetti, P., T. Joly and A. Baudot, 2006. Effect of antibiotics on thermodynamic properties of freezing media in rabbit species: A first calorimetric approach. Cryobiology, (53): 268-275.

SAS, 1998. User's Guide: Statistics, Version 6.12 Edition. SAS Institute, Cary, NC.

Tamuli, M. and P.F. Watson, 1994. Use of simple staining technique to distinguish acrosomal changes in the live sperm sub-population. Anim Reprod Sci., (35):247-254.

Thurston, L.M., K. Siggins, A.J. Mileham, P.F. Watson and W.V. Holt, 2002. Identification of amplified restriction fragment length polymorphism markers linked to genes controlling boar sperm viability following cryopreservation. Biology of Reproduction. (66): 545-554.

Velasco-Santamaria, Y.M., V.M. Medina-Robles and P.E. Cruz-Casallas, 2006. Cryopreservation of yamu (Brycon amazonicus) sperm for large scale fertilization. Aquaculture, 256: 264-271.

Viudes de Castro M.P., J.S. Vicente and R. Lavara, 1999. Effet du nombre de spermatozoïdes sur la fertilité de la semence conservée 24 heures chez le lapin, Ann. Zootech. (48):407-412. 
تجميد السائل المنوى للارانب: تأثير معدل الإسـالة ، سـلالة الارانب و فترة التحضين بعد

الأسالة

سامية زكريا مشرقي'، أبراهيم الوردانى"، علاء عبد السلام حميد"، هيام عبد الحليم عبداله'

1 - معه بحوث الإنتاج الحيواني، مركز البحوث الزراعية، وزارة الزراعة، الدقى، الجيزة، - قسم أنتاج

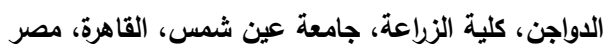

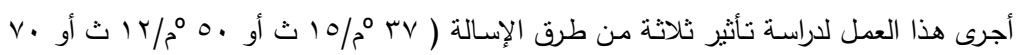

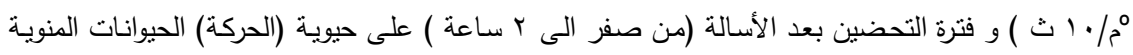

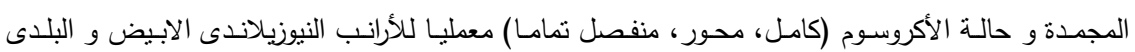

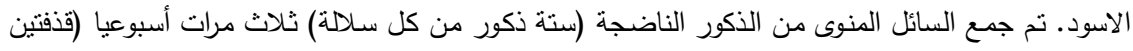

من كل ذكر فى كل مرة). أستخدم فقط السائل المنوى الذى يحتوى على أكثر من • •\% حيوية، تم تجميعه و تجميده فى النيتروجين السائل.

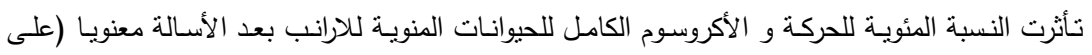

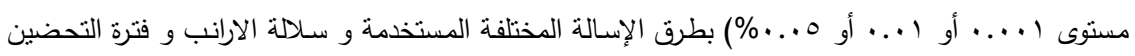

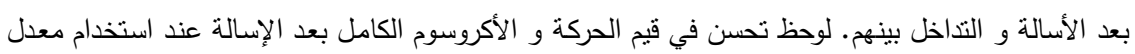

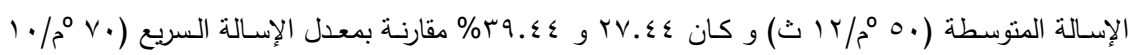

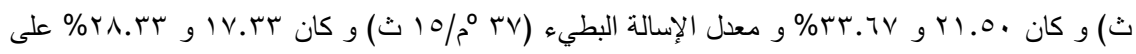

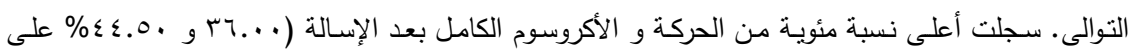

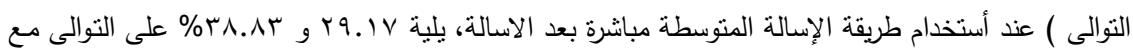

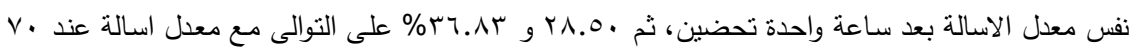

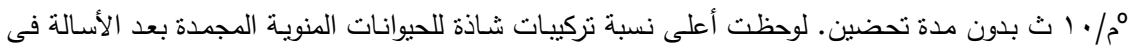
الارانب البلدى الاسود عند أستخدام معدلات الاسالة البطيئة أو السريعة مقارنة بالارانب النيوزيلاندى الابيض.

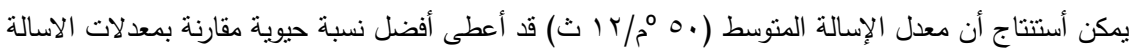

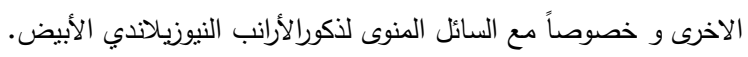

